\title{
Comparative Prevalence of Streak Canal and Intramammary Microorganisms and their Contemporaneous Association in a Dairy Cow and Buffalo Herd Lacking Mastitis Control Program
}

\author{
Shahid Javed $^{1}$, Ghulam Muhammad ${ }^{2} *$, Muhammad Saqib ${ }^{2}$ and Iftikhar Hussain ${ }^{1}$ \\ ${ }^{1}$ Institute of Microbiology, University of Agriculture, Faisalabad, Pakistan \\ ${ }^{2}$ Department of Clinical Medicine and Surgery, University of Agriculture, Faisalabad, Pakistan \\ *For correspondence: profdrgm54@gmail.com
}

\begin{abstract}
The present study was planned to investigate the prevalence of streak canal and intramammary infections in buffaloes and cows lacking any mastitis control program and to determine the contemporaneous association between streak canal and intramammary infections in these two dairy species. Streak canal swab and quarter foremilk samples were collected aseptically from 20 lactating mastitis free cows and buffaloes each in their first 2 months of second to third lactation and subjected to microbiological examination as per standard procedures. Isolates were speciated using commercially available kits. Contemporaneous association was defined as co-occurrence of a specific microorganism in streak canal swab and quarter foremilk sample of a particular teat simultaneously. The prevalence of streak canal infections as well as intramammary infections was higher in cows $(91.25 \%$ and $55 \%$, respectively) than in dairy buffaloes $(73.75 \%$, and $22.5 \%$, respectively). Of the 78 isolates recovered from streak canal swab samples of buffaloes, Staphylococcus aureus $(\mathrm{n}=18 ; 23.07 \%)$ was the most predominant organism followed by $S$. choromogenes $(\mathrm{n}=14)$, E. coli $(\mathrm{n}=6)$, unidentified esculin positive Streptococcus spp. $(\mathrm{n}=5)$. S. aureus $(\mathrm{n}=34)$ was the most frequent isolate recovered from the streak canals of cows followed by $S$. choromogenes $(\mathrm{n}=11)$, S. hyicus $(\mathrm{n}=8)$, Escherichia coli $(\mathrm{n}=8)$. In terms of frequency of isolation, $S$. aureus was the most predominant organism $(\mathrm{n}=6)$ recovered quarter foremilk samples of buffaloes followed by unidentified coagulase negative Staphylococcus spp. $(\mathrm{n}=3)$, Trueperella pyogenes (Corynebacterium pyogenes; $\mathrm{n}=3)$, unidentified Trueperella spp. and mixed species $(\mathrm{n}=3$ ). In the case of dairy cows, predominant organism recovered from quarter foremilk samples included $S$. aureus (n=13), Streptococcus agalactiae $(\mathrm{n}=4)$, yeast $(\mathrm{n}=4)$ and mixed species $(\mathrm{n}=4)$. Recovery of 44 and 27 isolates, respectively in cows and buffaloes was common to both streak canal swab and quarter foremilk samples (contemporaneous association). (C) 2015 Friends Science Publishers
\end{abstract}

Keywords: Streak canal infections; Intramammary infections; Contemporaneous association; Cows and buffaloes; Mastitis

\section{Introduction}

Several field investigations of economically significant livestock diseases in Pakistan have indicated that mastitis is the most important health problem of dairy cows and buffaloes (Cady et al., 1983; Ajmal, 1990; Hussain et al., 2005; Ali, 2008). It is reportedly one of the most important reasons for premature termination of lactation and involuntary culling of dairy buffaloes (McDowell et al., 1995) and cows (Samiullah et al., 2000) in Pakistan.

Microorganisms associated with mastitis almost invariably enter the udder through the streak canal (ductus papillaris), which is the orifice of mammary gland between internal milk secretary system and the external environment (Milne, 1977; Frandson et al., 2013). Streak canal is the first and the most important line of defense against the infections of the udder (Nickerson, 1990; Lacy-Hulbert, 1998).
Owing to its proximity to the external environment, streak canal a priori is very prone to develop infections. It is usually the initial site of infection in mastitis. To date, only a few reports documenting the occurrence of streak canal infections in cow have been published. These infections occur in lactating (Du Preez, 1986; Watts et al., 1991; Quirk et al., 2012) and non-lactating cows (Woolford et al., 2001) as well as heifers (Trinidad et al., 1990) and may persist for months. Du Preez (1986) suggested that bacteria colonizing the teat canal produce toxins that diffuse to the interior of the udder, thus producing an inflammatory response and damage to mammary parenchyma. Localized antibiotic infusions applied to the teat canal of cows at drying off have been shown to reduce new intramammary infections (Woolford et al., 2001). Nickerson et al. (1990) reported that iodophor (1.8\%) teat dip was $90 \%$ effective in preventing new $S$. aureus teat canal infections and $95.6 \%$

To cite this paper: Javed, S., G. Muhammad, M. Saqib and I. Hussain, 2015. Comparative prevalence of streak canal and intramammary microorganisms and their contemporaneous association in a dairy cow and buffalo herd lacking mastitis control program. Int. J. Agric. Biol., 17: 755-760 
effective in reducing the progression of $S$. aureus teat canal infections to intramammary infections.

Only a solitary report on the prevalence rate of streak canal infections and their contemporaneous association with the intramammary infections in dairy buffalo (Bubalus bubalis) is available in the literature (Tuteja et al., 2001). To our knowledge, there is no report comparing the prevalence rate of streak canal and intramammary infections in buffalo with that in cow in dairy herds lacking a mastitis control program. The present study was, therefore, designed to investigate the prevalence of streak canal and intramammary infections in buffaloes and cows under local Pakistani conditions wherein generally no mastitis control program is in place. A subsidiary objective was to determine the contemporaneous association between streak canal and intramammary infections in cows and buffalos.

\section{Materials and Methods}

\section{Prevalence of Streak Canal and Intramammary Infections in Buffaloes and Cows}

Experimental animals and management: Twenty lactating mastitis free cows and buffaloes each in their first 2 months of $2^{\text {nd }}$ to $3^{\text {rd }}$ lactation and maintained at Livestock Production Research Institute, Bahadurnagar, Okara were selected. All experimental animals were managed in a 'tiestall' cum loose housing system and were fed on concentrate mixture and sorghum + maize fodder. The experimental buffaloes were hosed once or twice daily depending upon the rigor of the weather. All experimental animals were hand milked twice daily between 3-5 a.m. and 3-5 p.m. No mastitis control measures (e.g., post-milking antiseptic teat dipping, dry period antibiotic therapy, mastitis vaccination, segregation of mastitic animals etc.) were in practice.

Collection of samples: Streak canal swab (using Calgiswab type 4, Spectrum Lab., Los Angles, USA) and quarter foremilk samples were taken from 20 lactating buffaloes and 20 lactating cows as per the techniques previously described (Hogan et al., 1990; National Mastitis Council, 1990; Muhammad, 1992; Quirk et al., 2012). Briefly, the preparatory steps for streak canal swab samples included: (1) teat ends were prepared for sampling by spraying them with $0.5 \%$ iodophor, (2) teat ends were wiped dry with single service individual paper towels, and (3) each teat end was scrubbed with 3 cotton swabs soaked in $70 \%$ ethanol. A nasopharyngeal swab (Calgiswab type 4) moistened in sterile phosphate buffered saline (PBS; $\mathrm{pH}$ 7.00) containing $0.1 \%$ sodium thiosulfate was carefully inserted approximately $2 \mathrm{~mm}$ into the teat meatus and rotated $360^{\circ}$. Using a scissors with ends sanitized with $70 \%$ ethanol, the swab head was clipped off into a $13 \times 100 \mathrm{~mm}$ test tube containing $250 \mu \mathrm{L}$ sterile PBS with $0.1 \%$ sodium thiosulfate. For quarter foremilk samples, each teat end was again sanitized with swabs soaked in $70 \%$ ethanol and quarter foremilk samples collected aseptically as previously described by National Mastitis Council (1990). Tubes containing streak canal swabs and milk samples were placed on crushed ice for transportation to the laboratory where plating of all samples was initiated within $1 \mathrm{~h}$ of collection.

Laboratory procedures: Tubes containing swab head in PBS rinse solution were vortexed for $10 \mathrm{sec}$ and then $50 \mu \mathrm{L}$ of the solution was inoculated onto one half of an esculin blood agar plate (5\% sheep blood and $0.1 \%$ esculin). Quarter foremilk samples $(0.01 \mathrm{~mL})$ were streaked onto one quadrant of esculin blood agar plate as described by National Mastitis Council (1990). Plates were examined after 24 and $48 \mathrm{~h}$ of incubation at $37^{\circ} \mathrm{C}$. Catalase-positive, Gram-positive cocci were presumptively identified as staphylococci and subjected to a tube coagulase test. Isolates of streptococci, coliforms and non-coliforms, Trueperella (Corynebacteria), yeast etc., were presumptively identified as per National Mastitis Council (1990) and then maintained at $-70^{\circ} \mathrm{C}$ in trypticase soya broth with $20 \%$ glycerol in cryogenic vials until speciated.

Species determination of isolates: Stock isolates were serially sub-cultured three times on Columbia blood agar and identified by utilizing commercial identification systems (Biomerieux, France) for Staphylococci, Streptococci, Trueperella (Corynebacterium), Gram negative rods and yeast.

\section{Determination of Comparative Contemporaneous Association Between Streak and Intramammary Infections in Cows and Buffaloes}

Contemporaneous association as used in the context of the present study referred to co-occurrence of a specific microorganism in streak canal swab and quarter foremilk sample of a particular teat simultaneously (Muhammad, 1992; Quirk et al., 2012).

\section{Results}

Comparative Prevalence of Streak Canal and Intramammary Infections in Cow and Buffalo

Of the 80 streak canal swab samples collected from 20 cows, $73(91.25 \%)$ yielded growth of 106 isolates belonging to 9 different microorganism categories. Similarly, of the 80 streak canal swab samples collected from 20 buffaloes, 59 (73.75\%) yielded growth of 78 isolates belonging to 8 different micro-organisms categories (Table 1). Staphylococcus aureus $(\mathrm{n}=34)$ was the most frequent isolate recovered from the streak canals of cows followed by $S$. choromogenes $(\mathrm{n}=11)$, S. hyicus $(\mathrm{n}=8)$, Escherichia coli $(\mathrm{n}=8)$, Streptococcus agalactiae $(\mathrm{n}=6)$, unidentified esculin positive Streptococcus spp. $(\mathrm{n}=5)$ and yeast species $\quad(n=5)$. Less frequently encountered 
Table 1: Comparative prevalence of streak canal isolates in cows and dairy buffaloes

\begin{tabular}{|c|c|c|}
\hline Microorganisms & $\begin{array}{l}\text { No. of } \\
\text { isolates } \\
\text { recovered } \\
\text { from the } \\
\text { streak } \\
\text { canal swab } \\
\text { samples of } \\
\text { cows } \\
(\mathrm{n}=20)\end{array}$ & $\begin{array}{l}\text { No. of } \\
\text { isolates } \\
\text { recovered } \\
\text { from the } \\
\text { streak } \\
\text { canal swab } \\
\text { samples of } \\
\text { buffaloes } \\
(\mathrm{n}=20)\end{array}$ \\
\hline Staphylococcus aureus & 34 & 18 \\
\hline Staphylococcus choromogenes & 11 & 14 \\
\hline Staphylococcus simulans & 3 & 1 \\
\hline Staphylococcus epidermidis & 1 & - \\
\hline Staphylococcus hyicus & 8 & 4 \\
\hline Staphylococcus xylosus & 2 & 1 \\
\hline Staphylococcus haemolyticus & - & 1 \\
\hline Staphylococcus warneri & 1 & 1 \\
\hline Staphylococcus saprophyticus & - & 1 \\
\hline Staphylococcus hominis & 1 & 2 \\
\hline Unidentifiedcoagulase negative Staphylococcus spp. & 2 & 3 \\
\hline Streptococcus agalactiae & 6 & 3 \\
\hline Streptococcus dysgalactiae & 1 & 2 \\
\hline Unidentified Esculin positive Streptococcus spp. & 5 & 5 \\
\hline Escherichia coli & 8 & 6 \\
\hline Trueperellapyogenes (Corynebacteriumpyogenes) & 3 & 1 \\
\hline Unidentified Corynebacterium spp. & 4 & 3 \\
\hline Bacillus spp. & 3 & 3 \\
\hline Yeast spp. & 5 & 4 \\
\hline Nocardia & 1 & - \\
\hline Mixed spp. & 4 & 3 \\
\hline Unidentified $s p p$. & 3 & 2 \\
\hline Total & 106 & 78 \\
\hline
\end{tabular}

microorganisms included unidentified Corynebacterium spp. $(\mathrm{n}=4)$, mixed spp. $(\mathrm{n}=4), S$. simulans $(\mathrm{n}=3), T$. pyogenes (Corynebacterium pyogenes; $\mathrm{n}=3$ ), Bacillus spp. $(\mathrm{n}=3)$ and unidentified $\operatorname{spp} .(\mathrm{n}=3)$. In a descending order, distribution of 78 isolates recovered from streak canal swab samples of buffaloes was as follows: $S$. aureus $(\mathrm{n}=18), S$. choromogenes $(\mathrm{n}=14), E$. coli $(\mathrm{n}=6)$, unidentified esculin positive Streptococcus spp. $(\mathrm{n}=5)$, S. hyicus $(\mathrm{n}=4)$, yeast spp. $(\mathrm{n}=4)$, unidentified coagulase negative Staphylococcus spp. $\quad(\mathrm{n}=3), \quad$ Str. agalactiae $\quad(\mathrm{n}=3), \quad$ unidentified Corynebacterium spp. $(\mathrm{n}=3)$, Bacillus spp. $(\mathrm{n}=3)$, and mixed spp. $(\mathrm{n}=3)$.

Of the 80 quarter foremilk samples of 20 cows subjected to microbiological examination, 44 (55\%) yielded growth of one or more than one microbial species (Table 2). $S$. aureus was the most frequent isolate recovered from quarter foremilk samples of cows accounting for $25.49 \%$ $(n=13)$ of the total isolates $(n=51)$ recovered from 80 quarter foremilk samples. The other organisms isolated from quarter foremilk samples of cows in their descending order included: Str. agalactiae $(\mathrm{n}=4)$, yeast $(\mathrm{n}=4)$, mixed species $(\mathrm{n}=4), S$. choromogenes $(\mathrm{n}=3)$, unidentified coagulase negative Staphylococcus spp. $(\mathrm{n}=3), T$. pyogenes $(\mathrm{n}=3)$, unidentified Corynebacterium spp. $(\mathrm{n}=3)$, unidentified spp. $(\mathrm{n}=3)$, S. hyicus $(\mathrm{n}=2)$, E. coli $(\mathrm{n}=2), S$. simulans $(\mathrm{n}=1), S$. epidermidis $(\mathrm{n}=1), S$. hominis $(\mathrm{n}=1)$, S. warneri $(\mathrm{n}=1)$, Str. dysgalactiae $(\mathrm{n}=1)$, unidentified esculin positive
Table 2: Comparative prevalence of microorganisms recovered from quarter foremilk samples of cows and dairy buffaloes

\begin{tabular}{|c|c|c|}
\hline Microorganisms & $\begin{array}{l}\text { No. of isolates } \\
\text { recovered from } \\
\text { quarter foremilk } \\
\text { samples of cows } \\
(n=20)\end{array}$ & $\begin{array}{l}\text { No. of isolates } \\
\text { recovered from } \\
\text { quarter foremilk } \\
\text { samples of } \\
\text { buffaloes }(n=20)\end{array}$ \\
\hline Staphylococcus aureus & 13 & $\overline{6}$ \\
\hline Staphylococcus simulans & 1 & - \\
\hline Staphylococcus choromogenes & 3 & 2 \\
\hline Staphylococcus epidermidis & 1 & - \\
\hline Staphylococcus hominis & 1 & 1 \\
\hline Staphylococcus xylosus & - & 1 \\
\hline Staphylococcus hyicus & 2 & 1 \\
\hline Staphylococcus warneri & 1 & - \\
\hline Unidentified coagulase negative & 3 & 3 \\
\hline Staphylococcus species & & \\
\hline Streptococcus agalactiae & 4 & 2 \\
\hline Streptococcus dysgalactiae & 1 & 1 \\
\hline Unidentified Esculin positive & 1 & 1 \\
\hline Streptococcus species & & \\
\hline Escherichia coli & 2 & 1 \\
\hline $\begin{array}{l}\text { Trueperellapyogenes } \\
\text { (Corynebacteriumpyogenes) }\end{array}$ & 3 & 3 \\
\hline Unidentified Corynebacterium spp. & 3 & 3 \\
\hline Bacillus spp. & 1 & 1 \\
\hline Yeast & 4 & 2 \\
\hline Mixed species & 4 & 3 \\
\hline Unidentified spp. & 3 & 2 \\
\hline Total & 51 & 33 \\
\hline
\end{tabular}

Streptococcus spp $(\mathrm{n}=1)$, and Bacillus spp. $(\mathrm{n}=1)$. Eighteen (22.5\%) buffalo quarters yielded growth of one or more than one microbial species (Table 2). Like in cows, S. aureus was the most predominant isolate $(\mathrm{n}=6 ; 18.18 \%)$ followed by unidentified coagulase negative Staphylococcus spp. $(\mathrm{n}=3)$, $T$. pyogenes $(\mathrm{n}=3)$, unidentified Corynebacterium spp. $(\mathrm{n}=3)$, mixed spp. $(\mathrm{n}=3), S$. chromogenese $(\mathrm{n}=2)$, Str. agalactiae $(\mathrm{n}=2)$, Yeast spp., unidentified spp. $(\mathrm{n}=2), S$. hominis $(\mathrm{n}=1), S$. xylosus $(\mathrm{n}=1)$, S. hyicus $(\mathrm{n}=1)$, Str. dysgalactiae $(\mathrm{n}=1)$, unidentified esculin positive Streptococcus spp. $(\mathrm{n}=1)$, E. coli $(\mathrm{n}=1)$, and Bacillus spp. $(\mathrm{n}=1)$.

Scrutiny of comparative contemporaneous association (defined in the context of the present study as co-occurrence of a microorganism in streak canal swab and quarter foremilk sample) of streak canal organisms with the intramammary organisms in cows and buffaloes revealed that recovery of 44 and 27 isolates, respectively in cows and buffaloes was common to both streak canal swab and quarter foremilk samples (Table 3).

\section{Comparative Contemporaneous Association Between Streak and Intramammary Infections in Cows and Buffalos}

Table 3 depicts comparative contemporaneous association (i.e., co-occurrence of streak canal and intramammary microorganisms; identity) of streak canal organisms with 
Table 3: Comparative contemporaneous association of streak canal organisms with the intramammary organisms in cows and buffaloes

\begin{tabular}{lll}
\hline Microorganisms & $\begin{array}{l}\text { No. of isolates } \\
\text { recovered } \\
\text { simultaneously } \\
\text { from streak canal } \\
\text { swab and foremilk } \\
\text { quarter samples of } \\
\text { cows (n= 20) }\end{array}$ & $\begin{array}{l}\text { No. of isolates } \\
\text { recovered } \\
\text { simultaneously } \\
\text { from streak canal } \\
\text { swab and foremilk } \\
\text { quarter samples of } \\
\text { buffaloes (n= 20) }\end{array}$ \\
\hline $\begin{array}{l}\text { Staphylococcus aureus } \\
\text { Staphylococcus choromogenes }\end{array}$ & 3 & 6 \\
Staphylococcus simulans & 12 & 2 \\
Staphylococcus epidermidis & 1 & - \\
Staphylococcus hyicus & 2 & - \\
Staphylococcus xylosus & - & 1 \\
Staphylococcus warneri & 1 & 1 \\
Staphylococcus hominis & 1 & - \\
Unidentified coagulase negative & 1 & 1 \\
Staphylococcus spp. & & 3 \\
Streptococcus agalactiae & 4 & \\
Streptococcus dysgalactiae & 1 & 2 \\
Unidentified Esculin positive & 1 & 1 \\
Streptococcus spp. & & \\
Escherichia coli & 2 & 1 \\
Trueperella pyogenes & 3 & 1 \\
(Corynebacterium pyogenes) & & 2 \\
Unidentified Corynebacterium spp. & 3 & 1 \\
Bacillus spp. & 1 & 2 \\
Yeast spp. & 3 & - \\
Mixed spp. & 2 & 27 \\
Unidentified spp. & 2 & \\
Total & 44 & \\
\hline
\end{tabular}

the intramammary organisms in cows and buffaloes. In cows $(n=20)$, a total of 44 isolates belonging to 18 microbial categories were recovered simultaneously from streak canal swab and foremilk quarter samples. The highest number of these isolates $(\mathrm{n}=12)$ belonged to $S$. aureus followed by Str. agalactiae $(\mathrm{n}=4), S$. choromogenes $(\mathrm{n}=3)$, $T$. pyogenes $(\mathrm{n}=3)$, unidentified Corynebacterium spp. $(\mathrm{n}=3)$ and yeast spp. $(\mathrm{n}=3)$. Two isolates each of $S$. hyicus, E. coli, mixed spp. and unidentified spp. were recovered simultaneously from streak canal and quarter foremilk samples of 20 cows. One isolates each of S. simulans, $S$. epidermidis, S. warneri, S. hominis, unidentified coagulase negative Staphylococcus spp., Str. dysgalactiae, unidentified esculin positive Streptococcus spp. and Bacillus spp. were recovered simultaneously from streak canal and quarter foremilk samples of 20 cows.

In a comparable number $(\mathrm{n}=20)$ of buffaloes sampled in the present study, 27 isolates of 15 microbial categories recovered from streak canal and quarter foremilk samples showed a contemporaneous association (identity). As in the cow, S. aureus was the species recovered most frequently $(\mathrm{n}=6)$ in a simultaneous manner from streak canal and quarter foremilk samples followed by unidentifiedcoagulase negative Staphylococcus spp. $(\mathrm{n}=3)$, S. choromogenes $(\mathrm{n}=$ 2), Str. agalactiae ( $\mathrm{n}=2)$, unidentified Corynebacterium spp. $(\mathrm{n}=2)$, Yeast spp. $(\mathrm{n}=2)$, Mixed spp. $(\mathrm{n}=2)$. One isolate each of S. hyicus $(\mathrm{n}=1), S$. xylosus $(\mathrm{n}=1), S$. hominis $(\mathrm{n}=1)$, Str. Dysgalactiae $(\mathrm{n}=1)$, unidentified esculin positive
Streptococcus spp. $(\mathrm{n}=1)$, E. coli $(\mathrm{n}=1), T$. pyogenes $(\mathrm{n}=1)$, and Bacillus spp. $(\mathrm{n}=1)$ were recovered simultaneously from streak canal and quarter foremilk samples of 20 buffaloes.

\section{Discussion}

Of the 80 streak canal swab samples each of cow and buffalo collected in the first two months of the lactation, 73 $(91.25 \%)$ and $59(73.75 \%)$ respectively were found infected with different microorganisms. Indian workers (Tuteja et al., 2001) documented a streak canal infection rate of $78.09 \%$ in dairy buffaloes at the time of drying off. A higher streak canal infection prevalence rate observed in the present study than that reported by these workers may relate in part at least to the difference in the sampling time with respect to lactation. A bacteriological survey of post pubertal, non-lactating dairy heifers indicated that $70 \%$ of the teat duct and $80 \%$ of the secretion samples obtained were infected with staphylococci that persisted for at least one year and well into the first lactation (Boddie et al., 1987), while about 44 and 46 percent of the Ohio State University (USA) dairy herd cows and heifers streak canal, respectively harbored staphylococci at calving (Muhammad, 1992). The higher prevalence of streak canal infections both in cows and buffaloes in the present study than that reported by this worker may partly be explained on the following grounds:

a) Muhammad (1992) reported only staphylococcal infections; infections by other microorganisms which might have infected streak canal were disregarded. Had organisms other than staphylococci been taken into consideration by this investigator, it is entirely possible that the prevalence rates of streak canal infections might have approached close to those observed in the present study.

b) Post-milking antiseptic teat dipping and dry period therapy were not practiced on the experimental animals of the present study. These mastitis control measures are effective in reducing the prevalence of streak canal and intramammary infections (Quirk et al., 2012). In the present study, of the 78 isolates recovered from streak canal swab samples of buffaloes, S. aureus $(\mathrm{n}=18 ; 23.07 \%)$ was the most predominant organism recovered followed by $S$. choromogenes $(\mathrm{n}=14)$, E. coli $(\mathrm{n}=6)$, unidentified esculin positive Streptococcus spp. $(\mathrm{n}=5), S$. hyicus $(\mathrm{n}=4)$, yeast spp. $(\mathrm{n}=4)$, unidentified coagulase negative Staphylococcus spp. $(\mathrm{n}=3)$, Str. agalactiae $(\mathrm{n}=3)$, unidentified Trueperella (Corynebacterium) spp. $(\mathrm{n}=3)$, Bacillus spp. $(\mathrm{n}=3)$, and mixed spp. $(\mathrm{n}=3)$. Of the 80 quarter foremilk samples of 20 cows subjected to microbiological examination, 44 (55\%) yielded growth of one or more than one microbial species. $S$. aureus was the most frequent isolate recovered from quarter foremilk samples of cows accounting for $25.49 \%(n=13)$ of the total isolates $(n=51)$ recovered from 80 quarter foremilk samples. In the case of buffaloes, microbiological examination of 80 quarter foremilk samples, 18 (22.5\%) quarters yielded growth of one or more than one microbial 
species. Like in cows, $S$. aureus was the most predominant isolate $(\mathrm{n}=6 ; 18.18 \%)$. Tuteja et al. (2001) reported that $S$. epidermidis was the most frequent isolate $(43.18 \%)$ recovered from streak canal samples of dairy buffaloes at drying off. This organism was followed by Corynebacterium spp. (27.27\%), unclassified streptococci (10.23\%), Str. dysgalactiae (9.09\%), Str. agalactiae $(7.96 \%)$ and S. aureus $(2.27 \%)$. Prevalence of streak canal infections was $78.09 \%$ whereas only $38.09 \%$ of the quarters were found to be infected. Among the microorganisms recovered from quarter milk samples, S. epidermidis $(37.50 \%)$ was the most frequent isolate followed by Corynebacterium spp. (27.5\%), $S$. aureus(10\%), Str. dysgalactiae (7.5\%), Str. agalactiae (5\%) and yeast $(2.5 \%)$. Nickerson et al. (1990) conducted a study to determine the prevalence of mastitis in breeding age and pregnant dairy heifers. The results indicated that IMIs were present in $97 \%$ of heifers and $75 \%$ of quarters. The predominant isolates were $S$. aureus, S. hyicus, and $S$. chromogenes. Iranian workers (Chavoshi and Husaini, 2012) reported CNS, streptococcus and bacillus species as the three most important pathogen groups isolated from CMT positive quarters of 400 dairy buffaloes. Only two quarters yielded the growth of $S$. aureus. The results of this study are at a variance with the findings of the present study as $S$. aureus was the most frequent isolate recovered from 80 foremilk quarters samples of each of cows and buffaloes. Coagulase negative staphylococci were the second most frequently isolated pathogens group in the present study. The notion that the prevalence of streak canal infection (diagnosed by means of streak canal swab samples) is higher than the intramammary infections diagnosed by culture of quarter foremilk samples (Du Preez, 1986; Tuteja et al., 2001) was borne out by the findings of the present study.

Several authors have reported that there appears to be a relationship between colonization of streak canal and infection of mammary gland (Forbes and Herbert, 1968; Appleman, 1970; Du Preez, 1986; Muhammad, 1992; Quirk et al., 2012). This conclusion was based on the observation that S. hyicus, S. aureus, S. xylosus, and S. chromogenes recovered from streak canal were also the predominant microorganisms recovered from secretion (milk) samples. Similarly, Forbes and Hebert (1968) observed that in lactating cows, the majority of $S$. aureus and $S$. epidermidis IMIs were preceded by streak canal colonization by these microorganisms, and they concluded that chronic IMIs may be maintained by the presence of streak canal colonization. In the present study, determination of comparative contemporaneous association (defined in the context of the present study as co-occurrence of a microorganism in streak canal swab and quarter foremilk samples of the same teat) of streak canal organisms with the intramammary organisms in cows and buffaloes revealed that recovery of 44 and 27 isolates, respectively in cows and buffaloes was common to both streak canal swab and quarter foremilk samples. Tuteja et al. (2001) reported that of the 40 infected quarters milk samples, $27(67.50 \%)$ were found to be infected with the same organisms as those infecting the teat canals. We know of no other report documenting the commonality (identity) of streak canal and intramammary isolates in dairy buffalo.

The commonality of a very high proportion of microorganisms to streak canal and milk samples (contemporaneous association) is probably reflective of the notion that streak canal infections serve as a source of microorganisms for the secretory tissue of the udders of cow and dairy buffalo. The present study is the preliminary investigation on the streak canal infections of buffaloes as well as on the contemporaneous association of microorganisms of streak canal and quarter milk samples of Pakistani dairy buffaloes.

Streak canal infections which do not progress upward to cause inflammation of the mammary gland are not usually diagnosed by mastitis diagnostic tests based on the detection of inflammation. Based on the International Dairy Federation (2005) criteria of somatic cell count (SCC) for mastitic quarters $\left(>200 \times 10^{3}\right.$ cells per ml of milk), Guha $e t$ al. (2012), reported that $32.20 \%$ of buffaloes and $20.89 \%$ of their quarters were categorized as suffering from mastitis. SCC had a lower sensitivity of mastitis diagnosis as compared to microbiological examination of milk samples (Guha et al., 2012). The explanation proffered by these investigators for lower sensitivity of SCC as compared to microbiological examination relates to recent latent infections which might be due to colonization of streak canals by mastitis pathogens. In consonance with the findings reported by Guha et al. (2012), Staphylococcus spp. were the most frequently isolated microorganisms from the milk in the present study.

A single infusion of dry period antibiotic into infected quarter's $\geq 45$ days (d) prepartum led to reduced incidence of IMIs by $59 \%$ at calving compared with pretreatment level (Nickerson et al., 1990). Even for the difficult to treat organisms like S. aureus, the cure rate was higher than $90 \%$. Prophylactic treatment of uninfected quarters $\geq 45 \mathrm{~d}$ prepartum resulted in a $93 \%$ reduction in new Streptococcal IMIs. The mean SCC was $50 \%$ lower at calving in treated heifers, and milk yield over the first 2 months of lactation was $10 \%$ greater than that of untreated controls. Heifers from herds using fly control had a lower prevalence of IMIs than herds not practicing this mastitis control measure.

\section{Conclusion}

The prevalence of streak canal infections as well as IMIs was higher in cow (91.25 and 55\%, respectively) than in dairy buffaloes (73.75 and $22.5 \%$, respectively). Recovery of 44 and 27 isolates, respectively in cows and buffaloes was common to both streak canal swab and quarter foremilk samples.

\section{Acknowledgements}

This manuscript is a part of Ph.D. dissertation research of 
the first author that was conducted in the Department of Clinical Medicine and Surgery, University of Agriculture, Faisalabad. The authors acknowledge the partial funding provided by University of Agriculture, Faisalabad under Promotion of Research Program.

\section{References}

Ajmal, M., 1990. Livestock Wealth of Pakistan. In: Proc. $3^{\text {rd }}$ Int. Cong. Pak. Vet. Med. Assoc. Uni. Grants Commission, pp: 379-392. Islamabad, Pakistan. Nov. 29, 1990

Ali, L., 2008. Epidemiology of mastitis in dairy buffalo and cow in Tehsil Samundri of district Faisalabad. Ph.D. Thesis, Department of Clinical Medicine and Surgery, University of Agriculture, Faisalabad, Pakistan

Appleman, R.D., 1970. Quantifying the genetic effects on the anatomy of the streak canal. In: Proc. $6^{\text {th }}$ Int. Conf. Cattle Diseases, Philadelphia. Part 6: 104-107

Boddie, R.L., S.C. Nickerson, W.E. Owens and J.L. Watt, 1987. Udder microflora in non-lactating heifers. Agric. Pract., 8: 23-25

Cady, R.A., S.K. Shah, E.C. Schermerhorn and R.E. McDowell, 1983. Factors affecting performance of Nili-Ravi buffaloes in Pakistan. $J$. Dairy Sci., 66: 578-586

Chavoshi, M., and J. Husaini, 2012. Buffalo subclinical mastitis bacterial pathogens in Iran. Int. Proc. Chem. Biol. Environ., 34: 143-147

Du Preez, J.H., 1986. The prevalence of teat canal infections in lactating dairy cows as determined from foremilk and teat canal swab samples. J. South Afr. Vet. Assoc., 57: 193-198

Forbes, D. and C.N. Hebert, 1968. Studies in the pathogenesis of staphylococcal mastitis. Vet. Rec., 82: 69-73

Frandson, R.D., W.L. Wilke and A.D. Fails, 2013. Anatomy and Physiology of Farm Animals. John Wiley and Sons, Philadelphia, USA

Guha, A., R. Guha and S. Gera, 2012. Comparison of somatic cell count, California mastitis test, chloride test and rennet coagulation time with bacterial culture examination to detect subclinical mastitis in riverine buffalo (Bubalus bubalis). Afr. J. Agric. Res., 7: 5578-5584

Hogan, J.S., K.L. Smith and D.A. Todhunter, 1990. Bacterial counts associated with recycled newspaper bedding. J. Dairy Sci., 73: 1756-1761

Hussain, M., M.A. Malik, Z. Fatima, and M. R. Yousaf, 2005. Participatory surveillance of livestock diseases in Islamabad capital territory. Int. J. Agric. Biol., 7: 567-570

International Dairy Federation (IDF), 2005. Diagnostic potential of California Mastitis Test to detect sub-clinical mastitis. Maastricht, Netherlands. pp: 15-19
Lacy-Hulbert, J., 1998. Physical characteristics of the teat canal and relationship with infection. In: Proceed. of the 37th National Mastitis Council Annual Meeting, pp: 54-61. St. Louis, Missouri, USA

McDowell, R.E., J.C. Wilk., S.K. Shah, D.S. Balain and G.H. Metry, 1995. Potential for commercial dairying with Buffalo. North Carolina State University Press, Chappel Hill, USA

Milne, J.R., 1977. Natural defense mechanisms against mastitis. In: Proc. Annual Meeting, National Mastitis Council. USA. pp: 19-38

Muhammad, G. 1992. Staphylococci of bovine mammary gland: conventional and molecular dynamics of infections, plasmid stability, reproducibility, and interspecific conjugal transfer of antibiotic resistance. Ph.D. Thesis, Dept. of Veterinary Preventive Medicine, The Ohio State University Columbus, Ohio, USA.

National Mastitis Council Inc., 1990. Microbiological procedures for the diagnosis of bovine udder infection. $3^{\text {rd }}$ Ed., Nat. Mastitis Council, Arlington, Virginia, USA

Nickerson, S.C., 1990. Defense mechanisms of the cow. In: Dairy Research Report. Hill Farm Research Station, Homer, Louisiana State University, USA. pp: 209-216

Nickerson, S.C., J.L. Watts, R.L. Boddie and C.H. Ray, 1990. Effect of postmilking teat antisepsis on teat canal infections in lactating dairy cow. J. Dairy Sci., 73: 373-380

Quirk, T., L.K. Fox, D.D. Hancock, J. Capper, J. Wenz and J. Park, 2012. Intramammary infections and teat canal colonization with coagulasenegative staphylococci after postmilking teat disinfection: speciesspecific responses. J. Dairy Sci., 95: 1906-1912

Samiullah, M.U.D.S., M. Arif and M. Khan, 2000. Frequency and causes of culling and mortality in Holstein-Friesian cattle in NWFP (Pakistan). J. Anim. Health Prod., 20: 22-24

Trinidad, P., S.C. Nickerson and T.K. Alley, 1990. Prevalence of intramammary infection and teat canal colonization in unbred and primigravid dairy heifers. J. Dairy Sci., 73: 107-114

Tuteja, F.C., M.P. Kapur, A. Sharma and B. Manuja, 2001.Prevalence of teat canal and intramammary infections in buffaloes at the time of drying-off. Ind. J. Compar. Microbiol. Immunol. Infec. Dis., 22: 6162

Watts, J.L., S.C. Nickerson, R.L. Boddie and C.H. Ray, 1991. Effects of a $1.94 \%$ sulfonic acid teat dip and a $1 \%$ iodophor teat dip on teat canal infections in lactating dairy cows. J. Dairy Sci., 74: 1115-1123

Woolford, M.W., J.H. Williamson, T.M. Day, S.J. Lacy-Hulbert and H.V. Henderson, 2001. Effect of localized antibiotic infusions applied to the teat-canal and teat sinus at drying-off on mastitis in the dryperiod and at calving. J. Dairy Res., 68: 551-558

(Received 28 December 2013; Accepted 15 February 2014) 